\title{
Reflections on a Respectable Revolution
}

\section{Charles Sampford ${ }^{*}$}

On 6 March 1991, I was somewhat surprised to find myself Foundation Dean of Law at Griffith University. Not only was the process quick, ${ }^{1}$ but it took my career in an unexpected direction. I had graduated in law just 12 years earlier and almost two-thirds of that time had been spent on full-time research ${ }^{2}-\mathrm{a}$ situation I fully expected to continue.

The diversion occurred because I had become very passionate about legal education and its possible improvement - sufficiently so to write about it, ${ }^{3}$ talk about it and make some substantive suggestions for reform that were introduced into a number of law schools. This passion was stimulated by the Pearce Report, ${ }^{4}$ which suggested that the first major failing of Australian law schools lacked a 'critical and theoretical dimension' without indicating what a 'critical and theoretical dimension' was or how it might be incorporated into legal curricula. The writings appeared to make sense to Professor Pearce who, as a co-opted member of the Griffith selection committee, suggested I be approached.

So began a hectic term as Dean when the ideas for the law school were refined and implemented. Just under one year later, on 23 February 1992, Sir Ninian Stephen, former Governor-General and High Court Judge delivered the keynote at the ceremony formally opening the Griffith Law School and hailed the curriculum as a 'revolution in legal education'. This was heady praise and accurately described our ambitions. However, I was a little nervous that this compliment might be too rich for a state whose conservatism was notorious.

It was soon apparent that I díd not need to worry. We were not, and we were not seen to be, wild-eyed revolutionaries enraged at the wrongs of the world and wildly striking out at the perceived causes. We shared a passionate

Professor Charles Sampford was appointed Foundation Dean and Professor of Law on 6 March 1991 and continues at Griffith as the Foundation Director of the Key Centre for Ethics, Law, Justice and Governance - the first nationally funded centre of excellence in ethics, law and governance. He almost single-handedly wrote the curriculum as well as the faculty's strategic plan.

1 Griffith had invited me to apply 37 days earlier and I had been offered it 17 days later.

2 From 1979 to 1983 , I was a DPhil student at Oxford to which I had returned on sabbatical in 1986. In 1988 and 1989, I was a Research Fellow at Monash and from early 1990, I had been a Principal Research Fellow and Deputy Director at the Centre for Philosophy and Public Issues at Melbourne University. The 'normal' academic work had been in 1983-87 at the Melbourne Law School from which I had been on leave for over three years.

3 Sampford and Wood (1987, 1988, 1989). The last-mentioned, and later writings, are collected in Goldring, Sampford and Simmonds (1998).

$4 \quad$ Pearce and Harding (1987). 
concern about the flaws in Australian legal education, an analysis of those flaws and a detailed strategy to address them. That strategy consisted of:

- a curriculum which had been refined through widespread consultation;

- a strategic plan to create a law school that could deliver that curriculum and take a national lead in interdisciplinary research; and

- a brief campaign to promote the curriculum to the profession.

It was, indeed, a 'respectable revolution': informed by the literature, grounded in the needs of those it was intended to serve and, like all successful revolutions, timely.

At the urging of Peter Birks, ${ }^{5}$ I have written at length about some of these matters. ${ }^{6}$ In that essay, I wrote about the academic and professional context in which the Griffith Law School was created. I also said something about my own road to Griffith, a good deal about the curriculum and its development, setting up the library, recruiting staff and developing the new subjects to be taught.

I will not repeat that history here, but rather say something more about the strategic goals we set and the campaign to promote the curriculum and to reflect on those goals and its achievements in the light of today's changing legal and institutional context.

\section{The Strategic Plan}

With only 12 months to the opening of the law school, work had to proceed on all fronts simultaneously - curriculum consultations, staffing, library, relations with the profession and getting to know the university. ${ }^{7}$ Sir Zelman Cowen, the Vice Chancellor's Advisor on Legal Education, had urged that the university should leave the major decisions until after the appointment of the Foundation Dean. (Indeed, he graciously told me he considered himself functus officio at that point, while saying that he was at my disposal in two senses - to help in ways I asked for as long as he could be of assistance. This was an offer that was, naturally, taken up with alacrity.) However, that good grace did mean that a lot of work had to be done.

Although I had already published a plan for a new core curriculum and had updated this for my interview by incorporating (with acknowledgment) some good ideas suggested by others, the strategic planning for the faculty which would deliver it started the morning after I was offered the job.

\section{Resources}

The first issue was that of resources - calculating what we needed and persuading the Vice Chancellor that this was a good investment for the

5 Challis Professor of Law at the University of Oxford and, for some time, Honorary Treasurer of the Society of Public Teachers of Law.

$6 \quad$ Sampford (1995), p 227.

7 I began immediately but could only work half-time for the first eight months because of work I could not abandon at the Ethics Centre in Melbourne, for which I was still working. 
university. The calculations were simple but showed the problems of law school funding (even then). We would require, at steady state, 22 per cent more per student per year ( $\$ 1000$ in 1990 dollars) at "steady state ${ }^{, 8}$ than the then best funded law school in Australia. I also wanted $\$ 150000$ in seed money for an interdisciplinary research centre - believing that this was not merely necessary to support the research work of staff but to access the only source of funds that could make the difference between a modestly funded law school and a well-funded one, and that team-based interdisciplinary research was not only the most important kind of research for law but would also attract the most funding. Quite naturally, the VC baulked. However, I was not just asking for this for the law school. I said - and I honestly believed - that Griffith could have Australia's best law school for the price of Australia's cheapest science faculty. If that was an exciting prospect, then I would put my heart and soul into it. If not, it wasn't worth doing and I certainly would not be doing it.

\section{Strategic Plans}

I also worked on a seven-year strategic plan which was in place by July 1991 . This was not formally required - indeed, there was no formal means by which faculty plans could be brought to the university for negotiation, endorsement and funding. However, I took the opportunity of our first budget submission for the next rolling triennium to provide a seven-year plan to bring the faculty to steady state.

There were three features of the strategic plan and the approach we took which I believe were crucial to all successful strategic plans. Good plans need to recognise the reasons why previous approaches are failing or falling short. I was particularly aware of three common reasons for such failure with three alternatives.

$1 \quad$ Seeking solutions to single problems. Many managers like to deal with problems and issues one at a time. This is particularly useful for day-today management within an effective structure. However, it is common that a solution to one problem exacerbates another. The most usual result is a regime of compromise solutions that cope with problems with minimum damage to other goals. The best plans are those that attempt to deal with both issues simultaneously - as I used put it, complex plans often require complex solutions. Complex mult1-faceted problems require complex multi-faceted solutions. It is not possible to deal with problems and issues sequentially when you are engaged in either the radical reform of an existing institution or the creation of a new one.

8 For example, when we reached the planned number of students after seven years - the initial figures were much higher, from 'infinity' in the first year when we had about $\$ 300000$ for staff and expenses (as well as about a million dollars for books) with no students, to $\$ 20000$ per EFTSU (effectıve full time student unit not the most empathetıc term for the raison d'être of academıa) in our first year and dropping to $\$ 5600$ per EFTSU. 
What is needed is a strategy to achieve the multiple goals that any dynamic institution will be pursuing.

2 Dichotomy traps. One of the reasons we do not see our way out of problems is that we see alternatives in terms of false dichotomies where the pursuit of one goal compromises another. Legal education was laced with such false dichotomies - with law schools apparently stranded between them, forced to make compromises. We were supposedly stranded between the academy and the profession, grappling with dichotomous choices between academic and practical, theoretical dimensions and clinical skills, content and context, educating for practice and educating for the range of careers to which law was put, teaching and research, breadth and depth. Resolving those dichotomies by developing strategies that would simultaneously address both was a key part of my previous writing and was a feature of the rationale for the curriculum.

3 A focus on individual rather than institutional issues. One of the greatest failings of our individualistic society is to conceive issues and problems in individual rather than institutional terms. By framing solutions in individual terms, we fail to provide realistic institutional answers. This was evident even in the negotiations for my coming to Griffith. I was aware that law schools were prepared to offer some very high salaries to foundation deans (including Griffith and another that was seeking me at the time). However, the real issue was how to create a law school that could take the lead in legal education and research. This would require ideas and funding — with the funding of the faculty more important than the salary of the Dean.

\section{The 1991 Plans}

In broadest terms, the 1991 Strategic Plan set out a two-year goal 'to give Griffith's Law School a national reputation as an innovator in legal education and research' and a 10-year goal to 'give it a national reputation as a law school of the first rank [of Australian law schools]'.

The plan aimed to do this by:

establishing Griffith as:

- the pioneer of integrated degree programmes;

- the leader in curriculum development, modernising the law curriculum to meet the needs of the twenty-first century;

- the employer of high-quality staff;

- a centre of high-quality research, especially in applied legal and philosophical research and legal education;

- a national law school (although most students will initially come to Griffith from the Brisbane Gold Coast corridor, the Law School aims to be sufficiently distinctive that a growing proportion will come because of its programmes and reputation);

- a law school with an international focus in its research and its teaching programmes at both undergraduate and graduate level. 
The rest of the strategy plan set out detailed plans for achieving those ends and the costs of doing so.

The aims of the curriculum were set out in more detail in a parallel document. ${ }^{9}$ They were to:

- cover the substantive areas of law identıfied by the professional admission bodies as necessary for practice;

- develop a modern law curriculum to meet the needs of the $21 \mathrm{st}$ Century, reflecting changes in the nature of law and legal practice since existing law curricula were designed in mid-century;

- create a law degree that not only provides the academic stage of a professional lawyer's education but also an education that is of use in the many other purposes to which law degrees are increasingly put;

- be a law school with an international focus in its research and its teaching programmes at both undergraduate and graduate level; and

- pioneer integrated degree programmes.

The key features of the curriculum designed to fulfill those aims were:

- updating the core curriculum to incorporate areas of law that are of growing importance to law in general and professional practice in particular (eg the Property Law course will include introductions to Resources and Intellectual Property Law);

- teaching of related areas of substantive law in larger and broader subjects so that students will have a broader understanding of the law and its functions withın society;

- grouping of these larger subjects into annual themes for the first three years:

1st year - laws that regulate interpersonal civil obligations;

2nd year - laws that regulate the creation and operation of organisations;

3rd year - laws that regulate the creation and transfer of property rights;

- incorporating the critical and theoretical dimensions of legal education as recommended by the Pearce Report;

- introducing the consideration of ethical issues in all of the core areas of law;

- improving clinical legal education and relevant skills training by placing them within the context of core subjects;

- emphasis on the increasingly national and international dimensions of the areas studied; and the

- pioneering of integrated degree programmes through a ten-point process of linking law and the disciplines with which we were integrating.

9 The curriculum, its rationale, justification and structure were set out in Sampford (1992). 


\section{The Campaign to 'Sell' the Curriculum}

The curriculum was the public centrepiece of the Griffith Law School. Ethically, I believed that a radical departure from pre-existing practice needed to be justified. Pragmatically, we needed the support of the profession to accept our students on graduation and, more immediately, we needed to gain the approval of three professional bodies (Solicitors' Board, Barristers' Board and Supreme Court) as a degree that met the subject requirements for admission to legal practice. Bond University had experienced some difficulty in getting its course approved - with the process taking time and money.

Sir Zelman persuaded the Governor to provide a reception at Government House to formally introduce me, and the curriculum, to the Queensland profession. This would give a great deal of legitimacy and respectability to we revolutionaries. However, I did not want to rely on this. The reception was designed to be a centrepiece of the campaign. I announced that 'there is no such thing as overkill'. I did not want a sirategy that merely delivered us a majority on the relevant approval authorities. I wanted to be convert opponents into supporters, supporters into enthusiasts and both supporters and enthusiasts into potential employers. The reception was scheduled for the week before the October 1991 meetings of the Solicitors' and Barristers' Boards. The plan was to present the overview both through a speech and a 'takeaway' pack consisting of the Griffith Law School glossy brochure and a six-page document outlining the structure, main features and rationale of the curriculum. The full submission was some 60 pages long, with detailed subject descriptions and other information required by the board. With the approval of the secretary to the two boards, this full submission could be sent by us to the members of the relevant boards. My plan was to have them couriered to their offices while they were at Government House. When they came to look at the larger document, I hoped that they would already be enthused about the overall approach and would not question or niggle about details about which they might otherwise differ.

In the weeks leading up to the reception, I lunched with the opinion leaders of the Bar and the Law Society. I asked the members of the Advisory Committee for a list of those whom they considered to be opinion leaders and to rank them in order of influence and likely sympathy. The plan was to hold a series of lunches in which the board member and I would lunch with the most sympathetic first and the least sympathetic last, in each case bringing someone from the previous lunch with us. John Griffin QC joined me for the barristers' lunches and Peter Short, then president of the Law Society, organised (and hosted) the lunches for solicitors.

The Solicitors' and Barristers' Boards met and, of the 60-plus members, only one person suggested that accreditation not be given immediately - a suggestion with which he did not persist when it was clear that all others were in favour. A few days later, the Supreme Court unanimously approved it as well. Not content with an overwhelming majority, we 'lunched' the one potential dissident and he was fully on board. Thus it was that the 'revolutionary' curriculum passed through what some had imagined to be the 
most conservative profession in Australia with the toughest and most restrictive rules for accreditation.

\section{Those Goals 11 Years On}

Eleven years later, they still seem worthy goals - all the worthier for having been so fulsomely achieved.

The curriculum met its set aims and we managed to build in all the key features - although integrated degree programs proved to be very hard work and introducing ethical issues into core subjects was initially patchier than I would have liked.

The curriculum was used to attract high-quality staff with congruent, if not identical, views on legal education. It was those staff who were responsible for winning more teaching awards and teaching grants than any other law school - and for consistently achieving the highest ratings for student satisfaction and employment rates. It was also that staff who made the research strategy so remarkably successful. From the beginning, we emphasised teambased interdisciplinary research. This delivered immediate results. In the next year, 1992, we won more new nationally competitive grants than any other Australian law school. Throughout the 1990s, our research performance on a per capita basis was better than any. By the end of the decade, with Australia's first Key Centre for Teaching and Research in Law to add to the rest of the faculty's research achievements, research centres run by Griffith's law academics were generating research income in excess of $\$ 3$ million a year.

\section{Flexibility}

Despite the detailed nature of the plan, it was not intended, or implemented, as a monolithic plan. It was not a rigid 'Schlieffen plan' that had to be implemented in full or fail. It was updated and modified each year. I expected my subsequent deans to actively do so and explicitly stated at the time I was appointed that I would 'not look over the shoulders of my successors'.

The plan set ambitious goals - reputation as the most innovative in two years and law school of the first rank in 10. When we secured our two-year goal in the first year, the next version of the strategic plan 'fessed up' to the real goal - that the Griffith Law School could be to the third wave of Australian law schools what the University of New South Wales Law School had been to the second, postwar wave. New South Wales gained a reputation for innovation in its first decade and become acknowledged as Australia's best in its second decade. Like all such goals, it was not all or nothing. I cheerfully admitted that we could live with failure - though second best would not be a result with which we would be satisfied. However, we would not get within range of second unless we had a vision and a plan for what best would be like and how we would get there.

All the evidence is that we are getting there. The strategic approach the faculty has taken seems to have built on, rather than being bound by, the ideas outlined in the original strategy plan - modifying, developing and responding to new opportunities. 


\section{'Great' Universities and 'Great' Law Schools: Reflections on a Current Debate}

The Federal Minister for Education, Brendan Nelson, has suggested that Australia should seek to have one or two universities in the world's top $100-$ that we should have at least one 'great' university. Few readers will expect much sympathy for that means of seeking academic excellence from a member of a university that lies between seventh and thirteenth on most competitive measures, and who is not only Foundation Dean of a Law School that aspires to be Australia's best but also the Foundation Director of Australia's only Australian Research Council-funded national centre in law. However, this is no new revelation.

Twenty-three years ago, I graduated from Melbourne Law School and went to Oxford to commence my research there. The university I left was part of the group of universities that now like to think of themselves as the 'great eight'. I went to a university that had as good a claim to greatness as any. However, it was at Oxford that I first decided that the idea of a 'great' university was fundamentally misconceived - what philosophers call a 'category mistake'. I was very aware that there were some marvellous groupings - law and philosophy in particular. But there were a lot of academics who had turned out to be quite ordinary and departments that gained more from their association with Oxford than Oxford could ever gain from the fact that it contained them.

The conclusion I drew then, as now, is that it is not universities that are great. Qualitative compliments are more appropriately directed at the academics themselves and the academic entities in which they interact and develop their ideas. A university might be called great in a statistical sense if it has more great schools and centres than others. For the university to be meaningfully great, it has to have means by which it identifies and nurtures areas of very high quality.

While sceptical of the notion of a great university, I embraced the idea of 'great' schools and naturally harboured ambitions that this would be one of them. While Sir Zelman's caution led me to suppress such thoughts in writing the first version of the Strategic Plan, I was not so circumspect with my colleagues. When Professor Nancy Viviani took me out to lunch and asked what sort of a law school I was setting up, I simply answered 'a great one'. And when Sir Anthony Mason, then Australia's Chief Justice, asked why I had given up a great research job in an applied philosophy centre 'just to set up a law school', my reply was: 'Chief Justice, this is no ordinary law school.'

Of course, 'great' can just be an empty adjective heaped meaninglessly on themselves by those who have nothing new to sell. In the current context, any attempt to define some universities as 'great' or 'world class' and provide funding on that basis will not assist the search for excellence and world leadership. First, the existing centres of national and international leadership are spread about the current university system. Second, giving preferential funding to some universities will stifle creative attempts to develop new and better schools and research groups. 
What Australia needs to do is to recognise that the goal should not be a 'great' or 'world class' university but a 'great' or 'world class' university system (something for which ministers have the responsibility). In such a system, universities should be able to make strategic choices about where they will invest their money to maximise excellence in their universities and to provide funding mechanisms that reward such excellence.

In this, the experience of the Griffith Law School, with its curriculum and the research centres it spawned, provides a model. Universities should be given the resources to make strategic choices and be rewarded on the basis of the relative success of those choices on meaningful academic performance indicators. This will focus the minds of universities on the quality of their strategic choices and the strategic plans they make to achieve them - and not on the basis of reputation or some claimed diffuse general excellence based on past (generally well-funded) performance.

\section{Globalising of Law: The Coming Issue for Legal Educators}

One of the ways that we sought to create a first-rate law school and curriculum was to identify where we thought law and the legal profession were going and to provide the education of lawyers who would go there.

Law schools should regularly ask those questions. Research centres must certainly do so. Several of our projects concern the profound changes in national and international governance that are being wrought by the forces of 'globalisation'. These changes are as profound and far reaching as those of the seventeenth and eighteenth centuries, which saw the rise of the strong sovereign state and its gradual and partial civilisation by enlightenment and post-enlightenment values of social and liberal democracy. We are now seeing the decline of strong sovereign states, a phenomenon with profound effects on many of our institutions and the assumptions that underlie them.

This is as true of the professions as it is of other institutions found in liberal democratic societies. In this context, it is notable that before the rise of the sovereign state, law and lawyering was a very cosmopolitan/international profession (at least through continental Europe) - supported by the cosmopolitan universities which are, it should be noted, of far greater antiquity than sovereign states. ${ }^{10}$ Indeed, the law and the military were the two most cosmopolitan/international professions. The rise of the sovereign state turned these into two of the most geographically bounded professions. With the relative decline of the sovereign state, we may wonder if law and lawyering will become far more international and transnational. ${ }^{11}$ This would have

10 The first known law lecturer was the monk Pepo, who taught in Bologna more than a thousand years ago.

"There is an alternative future to a world dominated by a single hegemonic empire. Despite the fears of some, and the unseemly enthusiasm of others, I doubt that this scenario will really come to pass. I have argued, and continue to believe, that the United States has more to gain than lose from international law and a series of rules that applies to everyone, including them. See Sampford (1999). This was later published as Sampford (2001). 
profound effects on those teaching and researching such 'reglobalising' professions. Reflecting on this process and the kind of profession and professional ethics that will go with it is a fascinating prospect with farreaching effects on the learned professions and the ways that universities provide for their education.

I suspect that the next great move in legal education will address this issue. I believe that Australia is in a particularly good position to make this contribution because we understand the world of strong sovereign states inhabited by the United States and the confederating states of the European Union. We also understand the vulnerabilities of smaller states that are not part of blocs. Our proximity to Asia provides us with an understanding of diversely different traditions. Therefore Griffith University may well have a role to play in the rethinking of the theory and practice of law in a globalising world and eventually in the delivery of the results.

\section{Conclusion}

During those first hectic years, I was asked if I was enjoying myself. My flip response was: 'I will enjoy myself in retrospect.'

When I do look back, it gives me immense pride to see how far the Griffith Law School has come. On 6 March 1991, I thought that it was possible for the Griffith Law School to do what the University of New South Wales had done and be the best of the new bunch in its first decade and the leader of Australian law schools in its second decade. I sought a curriculum that would attract and retain those with congruent ideas of legal education. I sought a research environment that would enrich the curriculum, support the research of its staff and provide a buffer in cash strapped times. However, if this was to become a reality, it would require the work of several deans and dozens of staff; it would require the continued support of the university and the profession. The fact that we have clearly been the most innovative law school over the past decade and are challenging the best on most objective performance criteria is a tribute to the hard work of all and their willingness to take risks that the ideas behind the Griffith Law School were more progressive and likely to produce better students and better research than their alternatives.

In retrospect, I am very glad to have played a part in this 'respectable revolution'. It was not always enjoyable, but it was worth doing and I am glad that it was done well.

\section{References}

Jack Goldring, Charles Sampford and Ralph Simmonds (1998) Legal Education: New Foundations, Cavendish, 1998

Denis Pearce, Enid Campbell, and Richard Harding (1987) A Disctpline Review of Law, AGPS.

Charles Sampford (1989) 'Rethinking the Core Curriculum' 12 Adelaide Law Review 38.

Charles Sampford (1992) Editorial Introduction 1 Griffith Law Revtew 1. 
Charles Sampford (1995) 'Starting a Law School from Scratch: The Griffith Experience' Reporter of the Society of Public Teachers of Law.

Charles Sampford (1996) 'Reflections of a Foundation Dean - the Griffith Experience' 26 Queensland Law Society Journal 227.

Charles Sampford (1999) 'Sovereignty and Intervention', Invited Plenary Paper, World Congress of Legal and Social Philosophy, World Trade Centre, New York, June.

Charles Sampford (2001) 'Sovereignty and Intervention' in T Campbell and B Leiser (eds), Human Rights in Theory and Practice, Ashgate.

Charles Sampford and David Wood (1987) 'Legal Theory in the Law School' 11(41) Bulletin of the Australian Society of Legal Philosophy 98.

Charles Sampford and David Wood (1988) "Theoretical Dimensions" of Legal Education - a Response to Pearce' 62 Australian Law Journal 32.

Charles Sampford and David Wood (1989) 'Legal Theory and Legal Education - the Next Step' 1 Legal Education Review 107. 